\title{
Resume Mata Kuliah Hukum Tata Negara
}

Nama : Selpi Yunianti

Nim : 10200120138

Kelas : HTN D

\section{PEMBAHASAN}

- Pengertian hukum tata negara

Menurut saya Hukum Tata Negara adalah suatu hukum atau peraturan hukum yang mengatur tentang organisasi Negara atau tatanan organisasi Negara. Sebelum berlanjut ke materi hukum tata negara, perlu diketahui apa sebenarnya itu hukum? Menurut pendapat saya hukum adalah aturan yang mengikat yang bersifat memaksa agar masyarakat mentaati tata tertib serta memberikan sanksi bagi yang melanggar.

- Fungsi Hukum Tata Negara

a. Sebagai dasar hukum pembentukan struktur organisasi dan hubungan tata kerja NKRI

b. Sebagai dasar hukum pembentukan sistem hukum Nasional Indonesia

- Sumber Hukum Tata Negara

1. Sumber hukum materil

Sumber hukum materil hukum tata negara adalah pancasila oleh karena itu semua peraturan perundang-undangan Indonesia harus berdasar, bersumber, dan tidak boleh bertentangan dengan pancasila.

2. Sumber hukum formal

Sumber hukum formil hukum tata negara Indonesia terdiri dari :

a) Hukum perundang-undangan

b) Hukum Adat ketatanegaraan

c) Hukum kebiasaan ketatanegaraan

d) Yurisprudensi ketatanegaraan.

3. Konvensi atau kebiasaan

4. Traktak atau perjanjian

5. Doktrin

6. Yurisprudensi

- Istilah Hukum Tata Negara (Hukum Publik)

1. Belanda (Straatsrecht)

2. Inggris (Constitutional law)

3. Prancis ( Droit Constituonnel)

4. Jerman (Verfassungsrecht)

- Adapun yang mencakup ruang lingkup Hukum Tata Negara yakni : 
1. Lembaga negara ( salah satunya eksekutif)

2. Kewenangan lembaga negara

a) Mahkamah Konstitusi membubarkan partai politik.

b) Pemberhentian presiden terkait usul DPR.

3. Bentuk dan sistem pemerintahan

4. Batasan dan pemisahan cabang kekuasaan (kekuasaan legislative, eksekutif, yudikatif)

5. Kontitusi

6. Prinsip dan hubungan antar negara

7. Hak Asasi Manusia

- Objek kajian Hukum Tata Negara

Objek kajian hukum tata negara yaitu kontitusi (negaranya dikelola berdasarkan aturan. Salah satu prinsip negara hukum (HAM) yaitu Axlo saxon atau common law, ialah memasukkan prinsip Hukum Tata Negara. Salah satu negara yang belum tentu memiliki KPK ialah Timur Leste.

- Hubungan HTN dan HAN

Hukum Tata Negara dengan Hukum Administrasi Negara itu mengatur negara dengan diam, karena hanya mengatur lembaga. Hukum Administrasi Negara atau biasa di singkat HAN adalah hukum yang mengatur dan mengikat aparatur negara dalam menjalankan fungsi, tugas, dan wewenang dalam penyelenggaraan pemerintahan/negara. Baik Hukum administrasi negara maupun hukum tata negara sama-sama menjadikan negara sebagai objek kajian.

$>$ Hukum Tata Negara menentukan lembaga negara dan wewenangnya baik vertikal maupun horizontal

$>$ Hukum Administrasi Negara mengatur penggunaan (operasional) wewenang oleh lembaga negara yang telah di berikan oleh Hukum Tata Negara.

- Sejarah ketatanegaraan Indonesia

Pada detik-detik bala tentara jepang di Indonesia mengadapi saat-saat yang amat kritis, maka pada tanggal 29 April 1945 Pemerintah Jepang di Jakarta membentuk suatu badan yang bernama Badan Penyelidik Usaha-Usaha Persiapan Kemerdekaan Indonesia (BPUPKI) Dokuritzu Zyunby Tyoosakai. Badan ini diketua oleh Dr. KRT Radjimsn Wediodiningrat, ketua muda RP. Soeroso, dan ketua muda dari pihak Jepang Tuan Itibanase Yosio, dengan jumlah anggotanya sebanyak 62 orang.

- Hukum administrasi negara

Hukum administrasi negara adalah peraturan hukum yang mengatur administrasi, yaitu hubungan antara warga negara dan pemerintahnya yang menjadi sebab sampai negar itu berfungsi. Menurut 
pendapat lain hukum administrasi adalah peraturan-peraturan yang harus diperhatikan oleh para pendukung kekuasaan pemerintahan yang memegang tugas pemerintahan dalam menjalankan kewajiban pemerintahan. Hukum administrasi negara merupakan hukum tata usaha yaitu keseluruhan aturan hukum yang menentukan cara bagaimana negara sebagai penguasa itu menjalankan usaha-usaha untuk memenuhi tugastugasnya atau cara bagaimana penguasa itu seharusnya bertingkah laku dalam mengusahakan tugas-tugasnya. Menurut victor situmorang hukum administrasi negara adalah hukum mengenai seluk-beluk administrasi negara (hukum administrasi negara heteronom) dan hukum operasional hasil ciptaan administrasi negara sendiri (hukum admnistrasi negara otonom) di dalam rangka memperlancar penyelenggaraan dari segala apa yang dikehendaki dan menjadi keputusan pemerintah di dalam rangka penu aian tugas-tugasnya.

Berdasarkan definisi hukum administrasi negara tersebut di atas dapat dijelaskan bahwa hukum administrasi negara itu mengatur negara dalam keadaan bergerak. Hukum tata negara dan administrasi negara merupakan dua jenis hukum yang dapat dibedakan, yakni hukum tata negara mengatur negara dalam keadaan diam, sedangkan hukum administrasi negara mengatur negara itu dalam keadaan bergerak. Akan tetapi, kedua hukum tersebut tidak dapat dipisahkan secara tajam. Hukum administrasi negara sangat erat hubungannya dengan hukum tata negara, karena kedua bidang hukum itu mempunyai objek yang sama, yaitu negara.

- Asas-asas hukum administrasi negara

Asas merupakan dasar dari suatu kaidah atau norma. Misalnya asas monogami dari Undang-Undang Nomor 1 Tahun 1974 tentang perkawinan, pada pasal 3 ayat (1).

- Ilmu politik adalah llmu yang membahas praktik politik serta teori dan deskripsi serta perilaku politik dan analisis sistem politik. Hubungan keduanya baik hukum tata negara maupun ilmu politik sama-sama menjadikan negara sebagai objek penyelidikannya.

- Konstitusi

Konstitusi merupakan hukum dasar sebagai pedoman atau acuan dalam penyelenggaraan suatu negara. Konstitusi sebagai hukum dasar dapat berupa hukum dasar yang tertulis dan juga hukum yang tidak tertulis. Di Indonesia sendiri menggunakan konstitusi yang tertulis yaitu undangundang Dasar 1945. Ketatanegaraan di Indonesia sudah mengalami beberapa kali pergantian, dari UUD 1945, Konstitusi Republik Indonesia Serikat atau di singkat RIS, UUD sementara, dan pada akhirnya kembali 
lagi ke UUD 1945. Kemudian terjadi perubahan pada tahun 1999, 2000, dan 2002. Dalam suatu negara konstitusi dijadikan sebagai pedoman atau sumber, apabila dalam suatu negara tidak menjadikan konstitusi sebagai pedoman atau sumber maka yang terjadi adalah ketidakaturan dalam negara.

Dalam waktu kurang lebih dua setengah tahun, konstituante hasil pemilihan umum 1995 belum berhasil membuat UUD yang bersifat tetap, oleh karena itu dalam siding pleno konstituante yang diselenggarakan, pada tanggal 22 April 1959, Presiden Soekarno menganjurkan agar konstituante menetapkan UUD 1945 sebagai undang-undang dasar yang bersifat tetap untuk NKRI. Setelah konstitusnte menyelenggarakan sidang dan mengadakan pemungutan suara sebanyak 3 kali, maka pada tanggal 5 juli 1959 presiden Soekarno menerbitkan Dekrit Presiden RI/Panglima tertinggi angkatan peran tentang kembali kepada UUD 1945 (Dekrit Presiden 5 Juli 1959) yang dimuat dalam Keppress Nomor 150 Tahun 1959. Dekrit Presiden 5 Juli 1959 tersebut menetapkan:

1. Pembubaran konstituante

2. UUD 1945 berlaku lagi

3. Pembentukan MPR yang terdiri atas anggota-anggota DPR ditambah dengan utusan-utusan dari daerah-daerah dan golongan-golongan dan pembentukan Dewan Pembentukan Dewan Pertimbangan Agung Sementara (DPAS) akan diselenggarakan dalam waktu yang sesingkatsingkatnya.

- Perubahan UUD 1945 berlangsung dalam satu rangkaian yang terdiri dari 4 tahapan yaitu:

1. Perubahan pertama dilakukan dalam sidang umum MPR Tahun 1999 (tanggal 14-21 Oktober 1999)

2. Perubahan kedua dilakukan pada Sidang tahunan MPR Tahun 2000 (tanggal 7-18 Agustus 2000)

3. Perubahan ketiga dilakukan sidang tahunan MPR Tahun 2001 (tanggal 1-9 November 2001)

4. Perubahan 2002 (tanggal 1-11 Agustus 2002)

Dengan mengingat bahwa perubahan UUD 1945 dilakukan dengan cara adendum, maka UUD 1945 setelah perubahan mempunyai susunan sebagai berikut :

1. UUD 1945 Naskah asli

2. Perubahan pertama UUD 1945

3. Perubahan kedua UUD 1945

4. Perubahan ketiga UUD 1945 


\section{Perubahan keempat UUD 1945}

Pada proses perubahan UUD 1945 dilakukan penyempurnaan sistem pemerintahan presidensial melalui :

a. Ketentuan pasal 1 ayat (2) UUD NRI Tahun 1945 (yang menyatakan Kedaulatan berada di tangan rakyat dan dilaksanakan menurut UUD) yang menyebabkan MPR tidak lagi berkedudukan sebagai lembaga tertinggi negara.

b. Dilakukannya penyeimbangan legitimasi dan kedudukan lembaga eksekutif dan lembaga legislative melalui pengaturan mengenai mekanisme pemilihan presiden dan wakil presiden yang dilakukan secara langsung oleh rakyat (pasal 6A UUD NRI Tahun 1945)

c. Melalui mekanisme pemberhentian presiden dan wakil presiden dalam masa jabatan (pasal 7A, pasal 7B, dan Pasal 8 UUD NRI Tahun 1945) sehingga presiden dan wakil presiden mempunyai legitimasi yang kuat dan tidak dapat diberhentikan dengan mudah, karena usulan pemberhentian presiden dan wakil presiden tidak lagi hanya melalui mekanisme politik tetapi harus melalui mekanisme hukum sesuai dengan ketentuan pasal ${ }_{7} \mathrm{~B}$ UUD NRI Tahun 1945.

Setelah perubahan UUD 1945 selesai dilakukan, MPR membentuk Komisi Konstitusi melalui Ketetapan MPR Nomor I/MPR/2002 tentang pembentukan komisi konstitusi. Tugas komisi konstitusi adalah melakukan pengkajian secara kompprehensif tentang perubahan UUD 1945, dan hasilnya sudah harus dilaporkan paling lambat pada sidang MPR Tahun 2003 untuk diputuskan.

Dalam keputusan MPR Nomor 4/MPR/2003 tersebut ditentukan hal-hal sebagai berikut:

1. Susunan Komisi Konstitusi :

a. 31 anggota yang dipilih oleh Badan Pekerja MPR dan ditetapkan oleh pimpinan MPR

b. Pimpinan ( 1 orang ketua, 2 orang swakil ketua, 1 orang sekretaris, dan 1 orang wakil sekretaris), yang dipilih dari dan oleh anggota

2. Komisi konstitusi bertanggung jawab kepada MPR melalui Badan Pekerja MPR.

3. Masa kerja komisi konstitusi adalah tujuh bulan terhitung sejak tanggal penetapan anggota komisi konstitusi

4. Hasil pengkajian diserahkan kepada badan pekerja MPR.

Pada sidang akhir masa jabatan MPR yang diselenggarakan pada tahun 2004, MPR menyatakan menerima baik naskah laporan hasil kerja Komisi Konstitusi, 
namun tidak disertai pernyataan tentanng tindak lanjut atas hasil kajian komisi konstitusi yang akan dilakukan oleh MPR. Hal ini dinyatakan dalam keputusan MPR Nomor 4/MPR/2004 tentang laporan badan pekerja MPR-RI mengenai hasil kajian komisi konstitusi.

Berikut tahun ketatanegaraan Indonesia mengalami pergantian yakni :
1. UUD 1945 (1945-1949)
2. UUD RIS (1949-1950)
3. UUD Sementara (1950-1959)
4. UUD 1945 (1945-Sekarang)

Beberapa hal alasan pembentukan lembaga-lembaga independen yaitu:

1. Untuk menjawab kebutuhan penyelenggaraan negara yang semakin kompleks, bisa jadi lembaga-lembaga negara yang ada itu dianggap kurang mampu untuk memenuhi kebutuhan-kebutuhan negara

2. Karena lembaga-lembaga negara yang ada di anggap tidak mampu untuk mengatasi persoalan-persoalan tertentu seperti pembentunkan KPK, karena penilain terhadap kedua institusi penegak hukum yang ada, kepolisian dan kejaksaan dianggap lamban dalam menangani tindak pidana korupsi, akhirnya disepakati.

- Sistem pemerintahan Indonesia

1. Macam-macam sistem pemerintahan

(1) Presidensial merupakan sistem pemerintahan negara republik, yaitu kekuasaan eksekutif dipilih melalui pemilu dan terpisah dari kekuasaan legislatif. Ciri-ciri sebagai berikut :

- Presiden sebagai kepala negara sekaligus sebagai kepala pemerintahan

- Presiden dipilih langsung oleh sebuah badan atau dewan pemilih

- Presiden tidak termasuk pemegang kekuasaan legislative dan tidak dapat memerintahkan pemilihan umum

- Presiden tidak dapat membubarkan kekuasaan legislative

- Presiden memiliki hak pregoratif untuk mengangkat dan memberhentikan menteri-menteri yang memimpin departemen dan nondepartemen

- Para menteri bertanggung jawab kepada presiden

(2) Parlementer merupakan sistem pemerintahan yang parlemennya memiliki peranan penting dalam pemerintahan. Dalam hal ini, 
parlemen berwenang mengangkat perdana menteri dan dapat menajtuhkan pemerintahan. Ciri-ciri sebagai berikut:

- Kabinet dipimpin oleh seorang perdana menteri yang dibentuk berdasarkan kekuasaan yang menguasai parlemen

- Anggota kabinet sebagian atau seluruhnya berasal dari anggota parlemen

- Kepala negara (raja/ratu atau presiden) dengan saran atau nasihat perdana menteri dapat membubarkan parlemen dan memerintahkan diadakan pemilihan umum

(3) Semipresidensial merupakan sistem pemerintahan yang menggabungkan sistem pemerintahan presidensial dan sistem pemerintahan parlementer, sering disebut dualisme eksekutif atau kepemimpinan rangkap karena memimpin presiden dan perdana menteri. Ciri-cirinya sebagai berikut:

- Presiden republik dipilih melalui hak pilih umum

- Presiden memiliki kekuasaan yang cukup besar

- Perdana menteri mengepalai kabinet yang bertanggung jawab kepada parlemen dan parlemen dapat menjatuhkkan perdana menteri melalui mosi tidak percaya

2. Sistem pemerintahan Indonesia

- Kedaulatan berada di tangan rakyat dan dilaksanakan menurut Undang-Undang Dasar (UUD 1945 Pasal 1 ayat 2)

- Negara Indonesia adalah negara yang berdasarkan atas hukum (UUD 1945 Pasal 1 ayat 3)

3. Peran lembaga negara sebagai pelaksana kedaulatan rakyat

- Majelis Permusyawaratan Rakyat (MPR) memiliki tugas dan wewenang sebagai berikut

1. Mengubah dan menetapkan UUD

2. Melantik presiden dan wakil presiden

3. Memberhentikan presiden dan wakil presiden dalam masa jabatannya menurut UUD

- Presiden, tugas dan wewenangnya yaitu

1. Menjalankan UU

2. Mengangkat daan memberhentikan menteri-menteri

3. Mengajukan RUU

4. Meberi gelar dan tanda jasa

5. Mengangkat duta dan konsul

6. Menetapkan perang dengan persetujuan DPR

7. Memegang kekuasaan tertinggi atas angkatan perang

- Dewan Perwakilan Rakyat (DPR), memiliki tugas sebagai berikut:

1. Menetapkan RAPBN 
2. Menetapkan RUU

3. Mengawasi jalannya pemerintahan

Hak-hak yang dimiliki DPR sebagai berikut:

1. Hak angket, yaitu hak untuk melakukan penyelidikan terhadap kebijakan pemerintah

2. Hak interpelasi, yaitu hak untuk meminta keterangan kepada presiden

3. Hak mengajukan usul RUU

4. Hak mengajukan usul atau pendapat

5. Hak imunitas, yaitu hak untuk tidak dituntut dalam pengadilan pernyataan dalam sidang

- Fungsi kedudukan peraturan perundang-undangan

1. Fungsi peraturan perundang-undangan

- Untuk memberikan kepastian hukum

- Untuk melindungi dan mengayomi hak-hak warga negara

- Untuk memberikan rasa keadilan

- Untuk menciptakan ketertiban dan ketentraman

2. Kedudukan peraturan perundang-undangan

- Sebagai hukum bagi warga negara

- Menjamin hak-hak dan kewajiban warga negara

- Pihak-pihak yang terlibat dalam penyusunan peraturan perundangundangan

- Dewan Perwakilan Rakyat

- Presiden 